\title{
PENINGKATAN KUALITAS PERTUMBUHAN LARVA PATIN (Pangasionodon hypopthalmus) YANG DISUPLEMENTASI VITAMIN D PADA ARTEMIA
}

\author{
Ningsih ${ }^{1}$ Armen Nainggolan ${ }^{2}$ \\ 1.2. Fakultas Perikanan dan Ilmu Kelautan Universitas Satya Negara Indonesia \\ nainggolanarmen@yahoo.com
}

\begin{abstract}
This study attempts to know the dosage suplementasi vitamin $d$ in naupli artemia to improve the quality of fish larvae patin and to megetahui influence the addition of vitamin $D$ in naupli artemia to fish larvae patin. Data observation ( parameter sr, the larvae (long and weight), and teratology) conducted using random design complete ( ral) in one factor with six treatment and three second .Treatment provided was the addition of vitamin d by doses 0 ppm, 20 ppm , 40 ppm , $60 \mathrm{ppm}, 80 \mathrm{ppm}$, and $100 \mathrm{ppm}$. The results of the study showed doses of vitamins $d$ the most efficient disuplementasikan in naupli artemia as feed fish larvae patin to improve the quality of fish larvae patin is $80 \mathrm{ppm}$.The influence of the addition of doses vitamin $d$ in naupli artemia for the larvae fish patin can be obtained that doses $80 \mathrm{ppm}$ value $\mathrm{sr}=94,6 \%, w t=9.5 \mathrm{mg}, \mathrm{lm}=0.9 \mathrm{~cm}$, and teratology 1 tail is doses most effective
\end{abstract}

Keywords : Fish larvae patin, Vitamin D, and Artemia

\begin{abstract}
ABSTRAK
Penelitian ini bertujuan untuk mengetahui dosis suplementasi vitamin D pada naupli artemia untuk peningkatan kualitas larva ikan patin dan untuk megetahui pengaruh penambahan vitamin $\mathrm{D}$ pada naupli artemia terhadap larva ikan patin. Data hasil pengamatan (Parameter SR, pertumbuhan larva (panjang dan bobot), dan abnormalitas) dilakukan menggunakan rancangan acak lengkap (RAL) dalam satu faktor dengan enam perlakuan dan tiga ulangan. Perlakuan yang diberikan adalah penambahan vitamin D dengan dosis 0 ppm, $20 \mathrm{ppm}, 40$ ppm, 60 ppm, 80 ppm, dan 100 ppm. Hasil penelitian menunjukan dosis vitamin D yang paling efisien yang disuplementasikan pada naupli artemia sebagai pakan larva ikan patin untuk peningkatan kualitas larva ikan patin adalah $80 \mathrm{ppm}$. Pengaruh penambahan dosis vitamin D pada naupli artemia terhadap larva ikan patin dapat diperoleh bahwa dosis $80 \mathrm{ppm}$ nilai $\mathrm{SR}=94,6 \%, \mathrm{Wt}=9,5 \mathrm{mg}, \mathrm{Lm}=$ $0,9 \mathrm{~cm}$, dan abnormalitas 1 ekor merupakan dosis yang paling efektif.
\end{abstract}

Kata kunci : Larva patin, Vitamin D, dan Artemia 


\section{PENDAHULUAN}

Ikan patin dikenal sebagai komoditas yang berprospek cerah, karena memiliki harga jual yang tinggi. Hal inilah yang menyebabkan ikan patin Siam diminati kebanyakan para pengusaha untuk membudidayakannya. Selain itu juga, ikan ini memiliki tingkat pertumbuhan yang cukup cepat. (Mahyuddin, 2010). Meskipun demikian, ketersediaan dipasar domestik ataupun manca negara masih relatif terbatas. Hal ini disebabkan ketersediaan benih ditingkat pembudidaya masih terbatas produksinya. Selain itu, pemeliharaan larva masih sanagat terbatas dan SR nya cenderung rendah.

Larva patin (Pangasionodon hypopthalmus) merupakan larva yang sangat rentan terhadap kematian karena larva ikan patin akan mudah stres, untuk mengurangi tingkat kematian pada larva diperlukan beberapa nutrisi dan pemberian pakan yang tepat jenis dan jumlahnya. Sampai saat ini larva ikan patin (Pangasionodon sp.) masih rendah sehingga produktivitasnya perlu ditingkatkan. Peningkatan produktivitas larva ikan patin diharapkan dapat meningkatkan ketersediaan benih yang pada akhirnya dapat meningkatkan produksi ikan patin konsumsi. Pakan yang biasa digunakan pada saat stadia larva hingga larva menjadi benih yang berukuran 19,05 mm adalah Artemia (Artemia salina) dan tubifex (Tubifex sp.). Artemia diberikan pada saat stadia larva hingga larva berumur lima hari. Kelebihan dari Artemia sebagai pakan alami adalah memiliki kandungan pigmen (canthaxanthin), protein, vitamin $\mathrm{C}$, dan beberapa asam lemak penting untuk pertumbuhan dan kelangsungan hidup larva (Hafezieh et al., 2009).

Abnormalitas pada larva ikan sering terjadi hal ini dapat berpengaruh signifikan terhadap tingkat SR yang semakin menurun. Salah satu akibat buruknya pada perkembangan organ. Organ yang tidak normal tidak akan berkembang dengan sempurna seperti organ lainnya. Bentuknya tidak dapat berubah, kecuali lebar dan panjangnya. Sampai saat ini belum ada satu pun teknik yang mampu mengubah atau menormalkan organ yang abnormal tetapi abnormal dapat dicegah dengan pemberian vitamin dengan dosis yang tepat (Arie, 2011). Vitamin D adalah salah datu jenis vitamin larut lemak prohormon yang juga dikenal dengan nama kalsiferol. Vitamin D sendiri memiliki 2 bentuk aktif yaitu yaitu vitamin D2 dan Vitamin D3. Vitamin D2 atau dikenal juga dengan nama ergokalsiferol ini berasal dari turunan senyawa kolesterol yang banyak ditemukan pada ragi dan tanaman. Vitamin D3 (kolekalsiferol) sendiri berasal dari turunan senyawa 7-dehidrokolesterol. (Wiguna, 2014). Fungsi utama dari vitamin D yaitu membantu pembentukan dan pemeliharaan tulang. Sementara fungsi khusus dari vitamin D ini adalah membantu pengerasan tulang, caranya dengan mengatur agar kalsium dan fosfor tersedia di dalam darah dan kemudian diendapkan pada proses pengerasan tulang. Oleh karena itu dilakukan penelitian mengenai penambahan vitamin $\mathrm{D}$ pada benih ikan patin untuk mengurangi tingkat kematian.

Hasil penelitian sebelumnya tentang kelangsungan hidup dan pertumbuhan larva ikan patin Pangasionodon hypopthalmus diberi artemia yang diperkaya dengan vitamin $\mathrm{C}$ didapatkan hasil yang terbaik untuk penambahan vitamin $\mathrm{C}$ dengan dosis $100 \mathrm{mg} / \mathrm{L}$ (Setiawati, 2013). Maka pada penilitian ini penulis akan melakukan penelitian dengan penambahan vitamin D melalui suplementasi pada artemia untuk meningkatkan kualitas larva ikan patin 


\section{METODOLOGI}

Penelitian ini dilakukan selama 11 bulan pada bulan April 2015 sampai Februari 2016. Pemeliharaan larva dan pemberiaan pakan uji dilakukan di Mitra Abadi, Kemang, Bogor. Analisa proksimat sampel dilakukan di Laboratorium Nutrisi Ikan BDP, Fakultas Perikanan dan Ilmu Kelautan IPB, Bogor. Analisa Uji Vitamin D dilakukan di Laboratorium Terpadu IPB. Peralatan yang digunakan dalam penelitian ini adalah akuarium, Water Quality Checker, Aerator, Selang, Wadah, Timbangan, Penggaris, Alat tulis, Kamera, Sendok, dan botol air mineral. Bahan yang digunakan dalam penelitian ini adalah Telur siap netas, Artemia, Vitamin D, dan garam. Metode yang digunakan adalah metode observasi dan pengujian yang terdiri dari 6 perlakuan dengan masing-masing 3 ulangan. Perlakuanya adalah penambahan vitamin D dengan dosis yang berbeda (0 ppm, 20 ppm, 40 ppm, 60 ppm, 80 ppm, dan 100 ppm). Parameter yang dilihat adalah SR, pertumbuhan larva $\{$ bobot (gram) dan pertambahan panjang $(\mathrm{cm})\}$, jumlah larva abnormal, analisis proksimat, analisis kandungan Vitamin D, dan kualitas air.

\section{HASIL DAN PEMBAHASAN}

\section{Tingkat Kelangsungan Hidup (SR) Larva Ikan Patin}

Hasil pengamatan terhadap SR secara menyeluruh dapat dilihat pada Gambar 1. Gambar tersebut menunjukan bahwa semakin tinggi pemberian dosis vitamin D memberikan hasil SR yang meningkat, akan tetapi pada dosis $100 \mathrm{ppm}$ mengalami penurunan SR dan persentasi SR pada dosis $100 \mathrm{ppm}$ lebih baik dari larva ikan patin yang tidak diberi vitamin D. Hal ini terjadi karena pada penambahan vitamin $\mathrm{D}$ dengan dosis $0 \mathrm{ppm}$, larva ikan patin masih bisa hidup walaupun dengan persentase SR yang rendah akibat beberapa larva ikan patin mengalami avitaminosis (kekurangan vitamin). Pada dosis $100 \mathrm{ppm}$, persentase SR menurun dibandingkan persentase SR dengan dosis yang lainnya (80 ppm dan $60 \mathrm{ppm}$ ), hal ini diperkirakan terjadi karena beberapa larva ikan patin yang mati disebabkan karena keracunan vitamin D (hypervitaminosis).

Berdasarkan perhitungan sidik ragam ANOVA diperoleh hasil perbedaan pemberian dosis vitamin D pada artemia yang diberikan untuk larva terhadap kelangsungan hidup larva tersebut memberikan pengaruh yang nyata dengan $(\mathrm{p}<0,05)$ dengan hasil data statistik yang lengkap untuk tingkat kelangsungn hidup larva ikan patin. Hasil uji statistik dari One-Sample Test menunjukan bahwa f hitung $=104,635 \mathrm{f}$ Tabel yang diperoleh dari Tabel statistik $\mathrm{f} \mathrm{0,05}$ adalah 3,11 dan Signifikan $5 \%=0,000$. Nilai Sig adalah $0,0001<0,05$ dan $F_{\text {hitung }}>F_{\text {tabel }}$ dengan angka 104,635 > 3.11 maka Ho ditolak dan H1 diterima, artinya Suplementasi Vitamin D pada artemia dengan dosis yang berbeda berpengaruh terhadap kelangsungan hidup larva ikan patin.

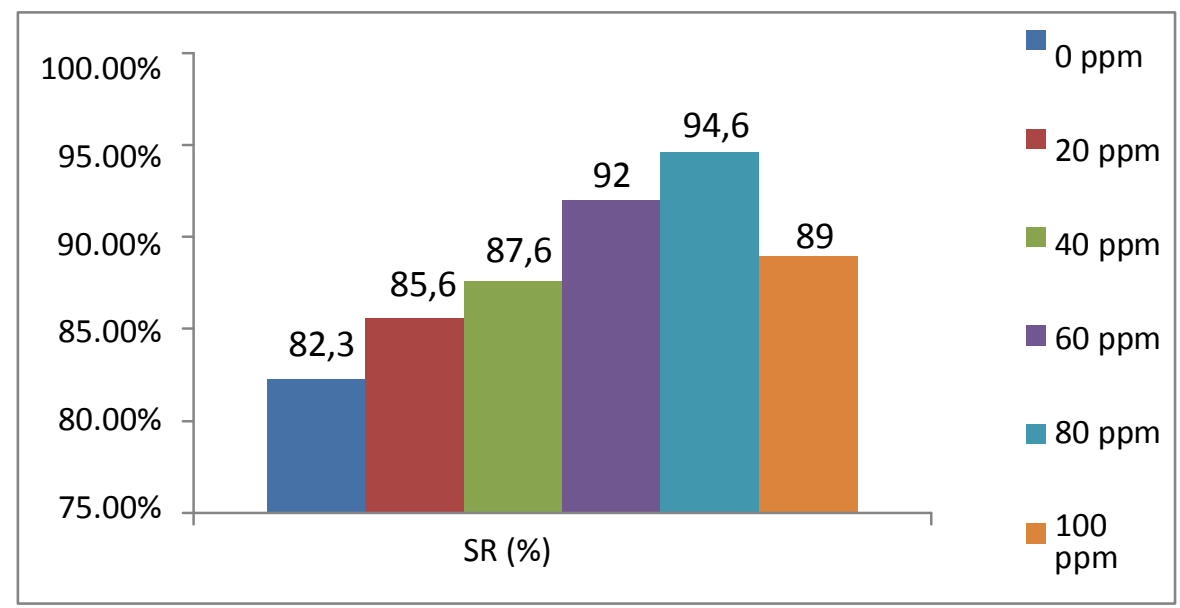

Gambar 1. Grafik Tingkat Kelangsungan Hidup Larva Ikan Patin 
Pemberian vitamin D yang menunjukan hasil yang baik untuk larva ikan patin adalah pada dosis $80 \mathrm{ppm}$. Hal ini sesuai dengan penelitian sebelumnya menggunakan Sample uji ikan salmon dengan pakan artemia yang diperkaya vitamin D oleh Salhi, 2014 yang mengatakan bahwa pemberian Artemia yang diperkaya vitamin $\mathrm{D}$ dosis $60 \mathrm{mg} / \mathrm{L}$ sebagai pakan alami memberikan kelangsungan hidup dan pertumbuhan ikan salmon paling baik. Artinya, pemberian vitamin D yang baik untuk ikan salmon adalah dengan dosis 60 ppm.

\section{Pertumbuhan (Pertambahan Panjang dan Bobot)}

Hasil pengamatan terhadap Panjang dan bobot secara menyeluruh dapat dilihat pada Gambar 2. Gambar tersebut menunjukan bahwa pertambahan berat larva ikan patin berbanding lurus dengan waktu penelitian. Pada dosis 80 pertambahan berat paling efektif selama penelitian dan pada dosis $0 \mathrm{ppm}$ atau tanpa penambahan vitamin $D$ pertambahan berat paling rendah. Hal ini menunjukkan bahwa larva ikan patin tumbuh seiring waktu pemeliharaan. grafik yang berwarna biru $(80 \mathrm{ppm})$ merupakan grafik yang paling tinggi dan pertumbuhannya paling baik dibandingkan dengan dosis yang lainnya

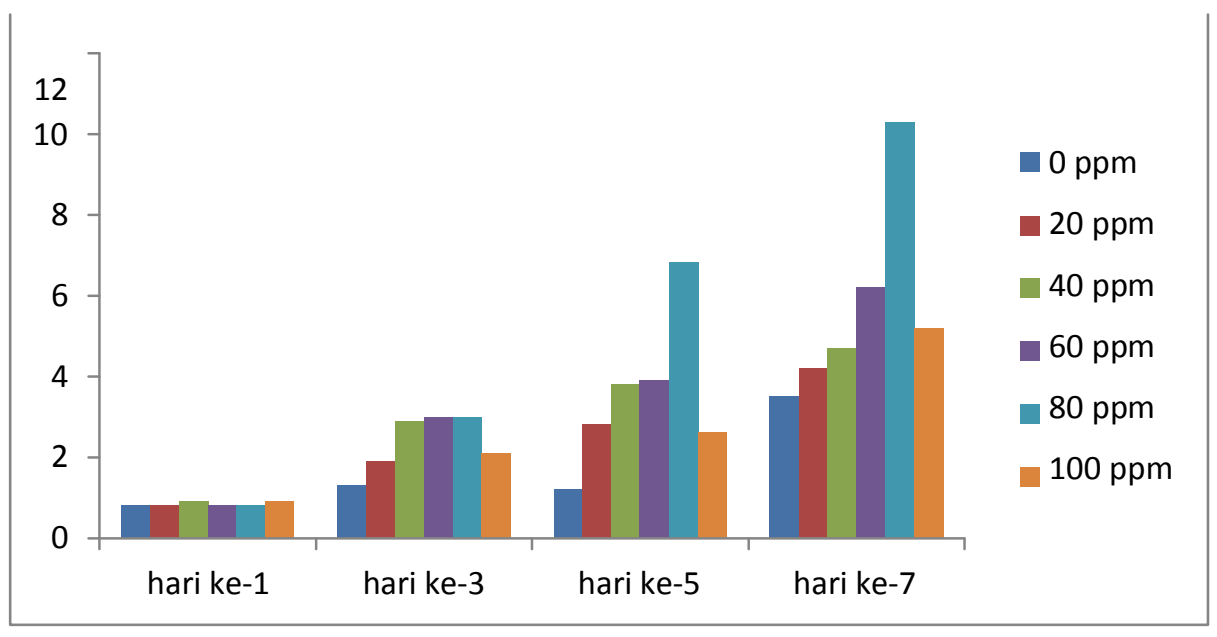

Gambar 2. Pertumbuhan Rata-rata Bobot Larva Ikan Patin

Pada data pertumbuhan bobot didapatkan hasil uji statistik dari One-Sample Test menunjukan bahwa f hitung $=225,413$ sementara $\mathrm{f}$ Tabel yang diperoleh dari Tabel statistik f 0,05 adalah 3,11 dan Signifikan 5\% =0,0001. Nilai Sig adalah $0,0001<0,05$ dan $F_{\text {hitung }}>F_{\text {tabel }}$ dengan angka 225,413 $>3.11$ maka Ho ditolak dan H1 diterima, artinya Suplementasi Vitamin D pada artemia dengan dosis yang berbeda berpengaruh terhadap pertambahan bobot larva ikan patin. Hal ini diperkirakan terjadi karena larva ikan patin sangat membutuhkan asupan vitamin $\mathrm{D}$ dari luar. Pemberian vitamin $\mathrm{D}$ dengan dosis yang tepat mengakibatkan larva ikan patin dapat tumbuh dengan optimal. Pada data pertumbuhan pertambahan panjang didapatkan hasil uji statistik dari One-Sample Test menunjukan bahwa f hitung $=8,65$ sementara $\mathrm{f}$ Tabel yang diperoleh dari Tabel statistik f 0,05 adalah 3,11 dan Signifikan $5 \%=0,001$. Nilai Sig adalah $0,001<0,05$ dan $F_{\text {hitung }}>F_{\text {tabel }}$ dengan angka 8,65 > 3.11 maka Ho ditolak dan H1 diterima, artinya Suplementasi Vitamin D pada artemia dengan dosis yang berbeda berpengaruh terhadap pertambahan panjang larva ikan patin. 


\section{Abnormalitas}

Hasil pengamatan terhadap Panjang dan bobot secara menyeluruh dapat dilihat pada Gambar 3. Sedangkan data abnormalitas dapat dilihat pada Tabel 1.

Hasil uji statistik dari One-Sample Test menunjukan bahwa f hitung = 29,133 sementara $\mathrm{f}$ Tabel yang diperoleh dari Tabel statistik f 0,05 adalah 3,11 dan Signifikan $5 \%=0,0001$. Nilai Sig adalah $0,0001<0,05$ dan $F_{\text {hitung }}>F_{\text {tabel }}$ dengan angka 29,133> 3.11 maka Ho ditolak da $\mathrm{H} 1$ diterima, artinya Suplementasi Vitamin D pada artemia dengan dosis yang berbeda berpengaruh terhadap jumlah abnormalitas larva ikan patin.

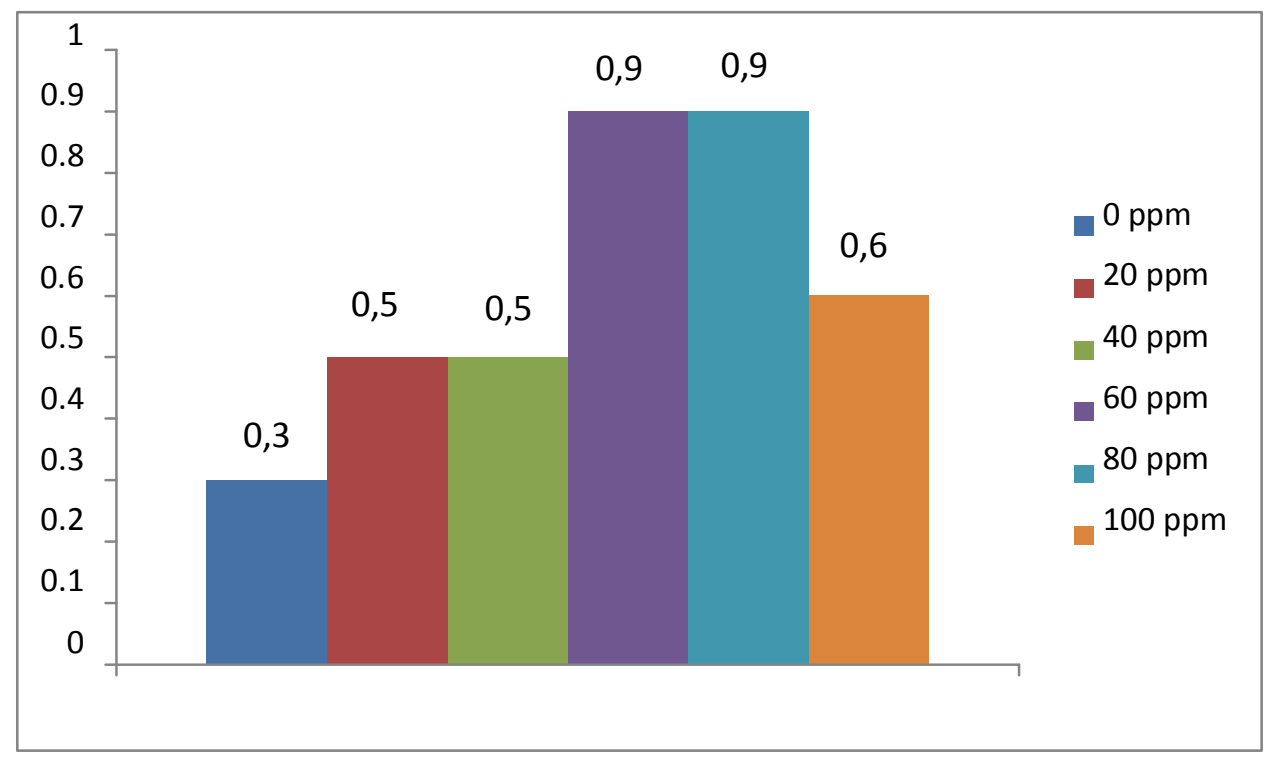

Gambar 3. Grafik abnormalitas larva ikan

Tabel 1. Abnormalitas larva ikan

\begin{tabular}{|c|c|c|c|}
\hline Perlakuan (dosis) & $\sum$ Abnormalitas (ekor) & F hitung & Signifikan $(\alpha)$ \\
\hline $0 \mathrm{ppm}$ & $11 \pm 2^{\mathrm{c}}$ & \multirow{6}{*}{29,133} & \multirow{6}{*}{0,0001} \\
\hline $20 \mathrm{ppm}$ & $7 \pm 1^{b}$ & & \\
\hline $40 \mathrm{ppm}$ & $2 \pm 1^{a}$ & & \\
\hline $60 \mathrm{ppm}$ & $3 \pm 1^{a}$ & & \\
\hline $80 \mathrm{ppm}$ & $1 \pm 1^{\mathrm{a}}$ & & \\
\hline $100 \mathrm{ppm}$ & $7 \pm 1^{b}$ & & \\
\hline
\end{tabular}

Pada Tabel 1 diperoleh hasil berdasarkan perhitungan sidik ragam ANOVA bahwa perbedaan pemberian dosis vitamin $\mathrm{D}$ pada artemia yang diberikan untuk larva terhadap jumlah abnormalitas larva tersebut memberikan pengaruh yang nyata $(\mathrm{p}<0,05)$. 


\section{Hasil Analisis Proksimat Larva Patin}

Hasil analisis proksimat larva ikan dapat dilihat pada Tabel 2. Hasil ini menunjukan nilai protein paling besar pada dosis $80 \mathrm{ppm}$ dan mengalami penurunan pada dosis $100 \mathrm{ppm}$ akan tetapi dosis 0 ppm lebih baik dari $100 \mathrm{ppm}$. Hal ini menunjukan bahwa protein yang terdapat pada larva ikan patin mempengaruhi pada pemberian dosis vitamin D karena peran protein yang seharusnya dioptimalkan untuk pertumbuhan dialihkan sebagai pengatur metabolisme tubuh akibat vitamin D yang dikonsumsi pada larva menjadikan metabolisme tubuh larva ikan patin tersebut tidak stabil.

Tabel 2. Komposisi Proksimat (\%) dalam Bobot Basah Larva Patin

\begin{tabular}{|c|c|c|c|c|c|c|}
\hline \multirow{2}{*}{ Kode sampel } & \multirow{2}{*}{$\begin{array}{c}\text { Kadar } \\
\text { Air }\end{array}$} & \multirow{2}{*}{$\begin{array}{c}\text { Kadar } \\
\text { Abu }\end{array}$} & \multirow{2}{*}{ Protein } & \multirow{2}{*}{ Lemak } & \multicolumn{2}{|c|}{ Karbohidrat } \\
\hline & & & & & Serat Kasar & BETN \\
\hline $\begin{array}{l}\text { Larva Ikan } \\
\text { Patin dosis } \\
0 \text { ppm }\end{array}$ & 70.34 & 5.52 & 15.69 & 3.58 & 3.42 & 0 \\
\hline $\begin{array}{l}\text { Larva Ikan } \\
\text { Patin dosis } \\
20 \text { ppm }\end{array}$ & 72.87 & 6.03 & 15.84 & 4.02 & 3.53 & 0 \\
\hline $\begin{array}{l}\text { Larva Ikan } \\
\text { Patin dosis } \\
40 \mathrm{ppm}\end{array}$ & 73.42 & 6.14 & 16.02 & 4.37 & 3.59 & 0 \\
\hline $\begin{array}{l}\text { Larva Ikan } \\
\text { Patin dosis } \\
60 \text { ppm }\end{array}$ & 75.09 & 6.28 & 16.27 & 4.65 & 4.06 & 0 \\
\hline $\begin{array}{l}\text { Larva Ikan } \\
\text { Patin dosis } \\
80 \text { ppm }\end{array}$ & 77.43 & 6.31 & 16.46 & 4.89 & 4.17 & 0 \\
\hline $\begin{array}{l}\text { Larva Ikan } \\
\text { Patin dosis } \\
100 \text { ppm }\end{array}$ & 80.98 & 6.42 & 15.45 & 3.39 & 3.29 & 0 \\
\hline
\end{tabular}

Ket: BETN = Bahan Ekstrak Tanpa Nitrogen

Pada Tabel 2 dapat dilihat nilai lemak yang terkandung pada larva ikan patin paling tinggi adalah $80 \mathrm{ppm}$ dan mengalami penurunan pada dosis $100 \mathrm{ppm}$ akan tetapi dosis 0 ppm lebih baik dari dosis 100 ppm. Hal ini menunjukan bahwa pemberian vitamin D dengan dosis yang tepat memperngaruhi kandungan lemak yang terdapat pada larva ikan patin tersebut karena peran lemak yang seharusnya sebagai salah satu sumber energi dialihkan untuk membantu proses pelarutan vitamin dalam tubuh larva ikan patin tersebut. 


\section{Hasil Analisis Komposisi Kandungan Vitamin D Larva Patin}

Hasil pengujian komposisi kandungan vitamin D pada masing- masing sample dapat dilihat pada Tabel 3..

Tabel 3. Data Komposisi Kandungan Vitamin D dalam 100 mg sample

\begin{tabular}{|l|c|}
\multicolumn{1}{|c|}{ Kode sampel } & Vitamin D (IU) \\
\hline $\begin{array}{l}\text { Larva Ikan Patin dosis } \\
\text { 0 ppm/500 ml artemia }\end{array}$ & 12 \\
\hline $\begin{array}{l}\text { Larva Ikan Patin dosis } \\
\mathbf{2 0} \text { ppm/500ml artemia }\end{array}$ & 59 \\
\hline $\begin{array}{l}\text { Larva Ikan Patin dosis } \\
\mathbf{4 0} \text { ppm/500ml artemia }\end{array}$ & 72 \\
\hline $\begin{array}{l}\text { Larva Ikan Patin dosis } \\
\text { 60 ppm/500ml artemia }\end{array}$ & 91 \\
\hline $\begin{array}{l}\text { Larva Ikan Patin dosis } \\
\text { 80 ppm/500ml artemia }\end{array}$ & 117 \\
\hline $\begin{array}{l}\text { Larva Ikan Patin dosis } \\
\text { 100 ppm/500ml artemia }\end{array}$ & 122 \\
\hline
\end{tabular}

Ket: IU = satuan International Unit

Tabel 3 menunjukkan bahwa semakin tinggi pemberian dosis vitamin D pada artemia sebagai pakan larva ikan patin maka akan semakin tinggi kandungan vitamin D pada larva ikan patin tersebut. Akan tetapi pemberian dosis vitamin D harus lah diberikan dengan dosis yang tepat jika kelebihan dosis vitamin D akan mengakibatkan penurunan kualitas pertumbuhan dan kelangsungan hidup larva karena larva ikan patin akan mengalami keracunan vitamin D.

\subsection{Kualitas Air}

Hasil pengukuran kualitas air dapat dilihat pada Tabel 4 dan Tabel 5. Tabel 4 dapat menunjukkan bahwa pada awal penelitian belum terdapat perbedaan. Hasil pengukuran kualitas air pada awal penelitian masih dalam kisaran baku mutu kualitas air pemeliharaan larva ikan patin dengan suhu $28-31{ }^{\circ} \mathrm{C}, \mathrm{pH} 6,5-8$, DO 3-8 mg/L, dan kekeruhan 4-6. 
Tabel 4. Hasil Pengukuran kualitas air pada awal penelitian

\begin{tabular}{|l|l|l|l|l|l|l|}
\hline \multirow{2}{*}{ Parameter } & \multicolumn{6}{|c|}{ Akuariu } \\
\cline { 2 - 7 } & $\begin{array}{l}\text { Dosis } \\
0 \mathrm{ppm}\end{array}$ & $\begin{array}{l}\text { Dosis } \\
20 \mathrm{ppm}\end{array}$ & $\begin{array}{l}\text { Dosis } \\
40 \mathrm{ppm}\end{array}$ & $\begin{array}{l}\text { Dosis } \\
60 \mathrm{ppm}\end{array}$ & $\begin{array}{l}\text { Dosis } \\
80 \mathrm{ppm}\end{array}$ & $\begin{array}{l}\text { Dosis } \\
100 \mathrm{ppm}\end{array}$ \\
\hline Suhu $\left({ }^{\circ} \mathrm{C}\right)$ & 30 & 30 & 30 & 30 & 30 & 30 \\
\hline $\mathrm{pH}$ & 7,5 & 7,5 & 7,5 & 7,5 & 7,5 & 7,5 \\
\hline DO (mg/L) & 6,85 & 6,85 & 6,85 & 6,85 & 6,85 & 6,85 \\
\hline $\begin{array}{l}\text { Kekeruhan } \\
\text { NTU }\end{array}$ & 4 & 4 & 4 & 4 & 4 & 4 \\
\hline
\end{tabular}

Hasil pengukuran kualitas air pada akhir penelitian dilakukan setelah 7 hari pemeliharaan larva. Pengukuran dilakukan pada setiap perlakuan dan pengulangan yang kemudian data dari pengulangan masing-masing perlakuan dirata-ratakan sehingga mendapatkan hasil seperti pada Tabel 5.

Tabel 5. Hasil Pengukuran kualitas air pada akhir penelitian

\begin{tabular}{|l|l|l|l|l|l|l|}
\hline \multirow{2}{*}{ Parameter } & \multicolumn{6}{|c|}{ Akuari } \\
\cline { 2 - 7 } & $\begin{array}{l}\text { Dosis } \\
0 \mathrm{ppm}\end{array}$ & $\begin{array}{l}\text { Dosis } \\
20 \mathrm{ppm}\end{array}$ & $\begin{array}{l}\text { Dosis } \\
40 \mathrm{ppm}\end{array}$ & $\begin{array}{l}\text { Dosis } \\
60 \mathrm{ppm}\end{array}$ & $\begin{array}{l}\text { Dosis } \\
80 \mathrm{ppm}\end{array}$ & $\begin{array}{l}\text { Dosis } \\
100 \mathrm{ppm}\end{array}$ \\
\hline Suhu $\left({ }^{\circ} \mathrm{C}\right)$ & 30 & 29,8 & 30,1 & 30,1 & 29,9 & 30,2 \\
\hline $\mathrm{pH}$ & 7,56 & 7,75 & 7,73 & 7,79 & 7,83 & 8,10 \\
\hline DO (mg/L) & 6,83 & 6,03 & 5,87 & 5,41 & 4,56 & 4,12 \\
\hline $\begin{array}{l}\text { Kekeruhan } \\
\text { NTU }\end{array}$ & 4 & 4 & 5 & 6 & 7 & 7 \\
\hline
\end{tabular}

Pada Tabel 4 dan Tabel 5 dapat dilihat perbedaan kualitas air sebelum dilakukan pemberian artemia dengan suplementasi vitamin $\mathrm{D}$, dan pemberian dosis vitamin $\mathrm{D}$ yang berbeda juga mempengaruhi suhu, $\mathrm{pH}$, DO, dan kekeruahan pada kualitas air tersebut. Semakin besar dosis vitamin D maka akan semakin tinggi pula suhu, $\mathrm{pH}$, dan tingkat kekeruhan pada akuarium tersebut dan sebaliknya semakin rendah dosis vitamins D maka akan semakin rendah suhu, $\mathrm{pH}$, dan tingkat kekeruhan pada akuarium tersebut. Hasil dari pegukuran DO mengalami menurunan pada pemberian dosis yang tinggi, dan pada pemberian dosis yang rendah DO pada akuarium tersebut semakin rendah. 


\section{KESIMPULAN DAN SARAN}

1. Kesimpulan

Kesimpulan penelitian ini adalah :

1. Dosis vitamin D yang paling efisien yang disuplementasikan pada artemia sebagai pakan larva ikan patin untuk peningkatan kualitas larva ikan patin adalah $80 \mathrm{ppm}$.

2. Pengaruh penambahan dosis vitamin $D$ pada naupli artemia terhadap larva ikan patin dapat diperoleh bahwa dosis $80 \mathrm{ppm}$ nilai $\mathrm{SR}=94,6 \%, \mathrm{Wt}=9,5$ $\mathrm{mg}, \mathrm{Lm}=0,9 \mathrm{~cm}$, dan abnormalitas 1 ekor merupakan dosis yang paling efektif. Dosis 0 ppm atau tanpa penambahan vitamin D nilai $\mathrm{SR}=82,3 \%$, $\mathrm{Wt}=2,7 \mathrm{mg}, \mathrm{Lm}=0,3 \mathrm{~cm}$, dan abnormalitas 11 ekor merupakan dosis yang paling tidak efektif.

2. Saran

Saran untuk penelitian selanjutnya perlu dikaji ulang mengenai biaya yang dikeluarkan jika pada pembenihan ikan patin menggunakan vitamin D dengan SR yang tinggi akan memperoleh biaya yang lebih efisien dibandingkan pada pembenihan ikan patin tanpa menggunakan vitamin D dengan SR yang rendah tapi tidak mengeluarkan biaya untuk pembelian vitamin D.

\section{DAFTAR PUSTAKA}

[Anonim]. 2008. Aspek Produksi Budidaya Pembenihan Ikan Patin. http://ikanmania/2008/01/22/aspek-produksi-budidaya-pembenihan-ikanpatin/.[5 April 2009, pk 14,50]

Arie, U. 2011. Pacu Pertumbuhan Ikan Nila. Penebar Swadaya Grup. Jakarta

Arifin, Z. 1987. Pemeliharaan Benih Ikan Patin (Pangasius pangasius).Direktorat Jenderal Perikanan. Jakarta

Buchanan, Mokoginta, I dan Jusadi, D. 2003. Jurnal Iktiologi Indonesia, volume

3, Nomor 1 : Pengaruh Kadar Vitamin E Dalam Pakan Terhadap Kualitas

Telur Ikan Patin Pangasionodon hypopthalmus. Fakultas Perikanan dan Ilmu Kelautan IPB. Bogor

Effendi, H. 2000. Telaah Kualitas Air Bagi Pengelolaan Sumber Daya dan Lingkungan Perairan. Fakultas Perikanan dan Ilmu Kelautan, IPB. Bogor. $258 \mathrm{p}$

Fauzan, M. 2010. Pembenihan, Pendederan, dan Pembesaran Ikan Patin. http://fauzan-mustopa.blogspot.com/2010/10/ikan-patin-siam-pangasiushypophthalmus.html [5 Januari 2015, pk 19,00]

Hafezieh, M., Kamarudin, M.S., Saad, C.R.B., Abd Sattar, M.K., Agh,N. Adn Hosseinpour, H. 2009. Effect of Enriched Artemia Urmiana on Growth, Survival and Composition of Larva Persian Sturgeon. Turkish Journal of Fisheries and Aquatic Sciences. 
Hamid, P, 2006. Teknology dan Engineering Budidaya Ikan Patin. Agromedia. Jakarta

Hendriana, A. 2010. Modul 2 Teknik Pemberian Pakan. Direktorat Program Diploma Institut Pertanian Bogor. Bogor

J, Lock, dkk. 2009. The Significance Of Vitamin D for Fish. Aquacultre Nutrition. Department of Animal Physiology, Institute for Water and Wetland Research, Faculty of Science, Radboud University Nijmegen, Nijmegen, The Netherlands

Kementrian Kelautan dan Perikanan . 2009. Proyeksi Produksi Perikanan Budidaya Menurut Komoditas Utama. Jakarta

Lagler, K. F. 1956. Dalam Jurnal Akuakultur Indonesia 12. Setiawati, M., Putri, D., dan Jusadi, D. 2013. Kelangsungan dan Pertumbuhan Larva Ikan Patin Pangasionodon hypopthalmus Diberi Artemia yang Diperkaya dengan Vitamin C. Departemen Budidaya Perikanan. Fakultas Perikanan dan Ilmu Kelautan. IPB

Mahyuddin, K. 2010. Panduan Lengkap Agribisnis Patin. Jakarta: Penebar Swadaya.

Meade, J.W. 1989. Aquaculture Manajement. Champman \& Hall. Washington. $174 \mathrm{p}$

Salhi, M. 2014. Survival and Growth of Salmon (Oncorhynchus masou) by Artemia Nauplii Enriched with vitamin $D$ Laboratorio de Recursos Naturales, Instituto de Ecologi'a y Ciencias Ambientales, Facultad de Ciencias, Universidad de la Repu' blica, Montevideo, Uruguay.

Sauvage, 1878. Dalam Jurnal Riset Akuakultur, volume 6 nomor 2. Iswanto, Bambang. 2011. Embriogenigas Dan Perkembangan Larva Patin Hasil Hibridisasi Antara Betina Ikan Patin Siam (Pangasionodon hypopthalmus). Pusat Penelitian dan Pengembangan Perikanan Budidaya. KKP

Setiawati, M., Putri, D., dan Jusadi, D. 2013. Kelangsungan dan Pertumbuhan Larva Ikan Patin Pangasionodon hypopthalmus Diberi Artemia yang Diperkaya dengan Vitamin C. Departemen Budidaya Perikanan. Fakultas Perikanan dan Ilmu Kelautan. IPB

Sunarma, A. 2007. Panduan Singkat Teknik Pembenihan Ikan Patin (Pangasius hypopyhalmus). Sukabumi : BBPBAT

Tangendjaja and Cgien. 2007. Journal Of Animal And Feed Sciences. Effect Of Replacing Fish Meal With Ensiled Catfish (Pangasionodon hypopthalmus) by-Products On The Performance And Carcass Quality Of Finishing Pigs. Swedish University Of Agricultural Scienies. Swedish

Wiguna, C. 2014. Vitamin D (Kalsiferol). http://ilmukesehatan.com/vitamin-dkalsiferol/ [5 Januari 2015,pk 19,00]

Zonneveld, N., and E.A.Huisman, J.H. Boon.1991. Prinsip-Prinsip Budidaya Ikan. PT Gramedia Pustaka Utama. Jakarta. 318p. 